\title{
Az SGLT2-gátló kezelés evidenciái a csökkent ejekciós frakcióval járó szívelégtelenség terápiájában
}

\author{
Sepp Róbert
}

\author{
Szegedi Tudományegyetem, Belgyógyászati Klinika, Non-Invazív Kardiológiai Részleg, Szeged \\ Levelezési cím: Prof. Dr. Sepp Róbert, Szegedi Tudományegyetem, Belgyógyászati Klinika, Noninvazív Kardiológiai \\ Részleg, 6725 Szeged, Semmelweis u 8., e-mail: sepprobert@gmail.com
}

\begin{abstract}
A nátrium-glükóz-kotranszporter-2 (sodium-glucose co-transporter 2, SGLT2) -inhibitorok megjelenése a csökkent ejekciós frakcióval járó szívelégtelenség (heart failure with reduced ejection fraction, HFrEF) terápiájában az elmúlt évek egyik legjelentősebb és legnagyobb hatású sikertörténeteként értékelhető. Az SGLT2-gátlók hatásosságát HFrEF-ben a klinikai vizsgálatok teljes spektruma igazolja, a kardiovaszkuláris (CV) kimeneti végpontú vizsgálatok és azok alcsoportelemzéseitől kezdve, a CV-vizsgálatok metaanalízisein, „real-world” adatokon át egészen a célzott HFrEF-betegpopulációkat vizsgáló randomizált, placebokontrollált, multicentrikus vizsgálatokkal bezárólag. Fenti vizsgálatok konzisztens módon igazolják az SGLT2-gátló szerek morbiditás- és mortalitáscsökkentő hatását HFrEF-betegekben, fennálló diabétesztől függetlenül. Ezen adatokon alapulva vezető szakmai szervezetek már jelenleg is ajánlásként fogalmazzák meg az SGLT2-gátlók használatát a szívelégtelenség hospitalizációjának megelőzése céljából 2-es típusú diabéteszben szenvedő betegekben, illetve specifikusan a dapagliflozin vagy empagliflozin alkalmazását a szívelégtelenség miatti hospitalizáció és CV-halálozás kombinált rizikójának csökkentésére tünetes HFrEF-betegekben, diabétesz fennálltától függetlenül. Az Európai Kardiológus Társaság legújabb, 2021-ben megjelenő szívelégtelenséggel kapcsolatos irányelve minden bizonnyal szintén be fogja építeni az SGLT2-gátló terápiát a HFrEF gyógyszeres kezelésének algoritmusába.

Kulcsszavak: csökkent ejekciós frakcióval járó szívelégtelenség, SGLT2-gátló terápia, kardiovaszkuláris rizikó, szívelégtelenség miatti hospitalizáció
\end{abstract}

Evidence for SGLT2 inhibitor therapy in the treatment of heart failure with reduced ejection fraction The emerge of sodium-glucose co-transporter 2 (SGLT2) inhibitors in the treatment of heart failure with reduced ejection fraction (HFrEF) may be labelled as the most important and most influential success story in recent years. The effectiveness of SGLT2 inhibitors in the treatment of HFrEF are proved by the full spectrum of clinical studies, starting from cardiovascular (CV) outcome studies and their sub-group analyses, through meta-analyses of CV outcome studies and „real-world” data, ending in randomized, placebo controlled, multicentric studies assessing targeted patient populations with HFrEF. All the above studies consistently prove the effect on risk reduction regarding mortality and morbidity of SGLT2 inhibitors, independent of the diabetic status of patients. Based on this data leading scientific societies formulate recommendations even today on the use of SGLT2 inhibitors in preventing hospitalization for heart failure in patients with type 2 diabetes, and recommend specifically dapagliflozin and empagliflozin in symptomatic patients with HFrEF, independent of their diabetic status. The newest clinical guideline on heart failure of the European Society of Cardiology, due in 2021, is also expected to make recommendations on the incorporation of SGLT2 inhibitors into the algorithm of medical treatment of heart failure.

Keywords: heart failure with reduced ejection fraction, SGLT2 inhibitor therapy, cardiovascular risk, heart failure hospitalization

A kézirat 2020. 11. 23-án érkezett a szerkesztőségbe, 2020. 12. 03-án került elfogadásra. 


\section{Bevezetés}

A nátrium-glükóz-kotranszporter-2 (sodium-glucose cotransporter 2, SGLT2) -inhibitorok megjelenése a csökkent ejekciós frakcióval járó szívelégtelenség (heart failure with reduced ejection fraction, HFrEF) terápiájában az elmúlt évek egyik legjelentősebb és legnagyobb hatású sikertörténeteként értékelhetö. A gyógyszercsoport rendkívül komplex hatásmechanizmus révén (1) kedvezően befolyásolja a szívelégtelenség (SzE) számos alapvető patomechanizmusát, és immáron célzott klinikai vizsgálatok által bizonyítottan, legalábbis két leginkább vizsgált hatóanyaga, a dapagliflozin és empagliflozin vonatkozásában, csökkenti a HFrEF-ben szenvedő betegek morbiditását és mortalitását $(2,3)$.

Az SGLT2-gátlók HFrEF-ben való alkalmazhatóságának lehetősége az antidiabetikumok kardiovaszkuláris biztonságossági vizsgálatainak eredményei alapján merült fel. Utóbbiakra a roziglitazon SzE súlyosbodásával és az SzE miatti hospitalizáció növekedésével kapcsolatos adatok miatt kötelezték a gyógyszergyártókat, hiszen a szer első forgalomba hozatala óta ismert volt, hogy a roziglitazon alkalmazása folyadékretencióval és a szívelégtelenség dekompenzációjának fokozott kockázatával jár együtt (4). Utóbbi miatt a roziglitazon alkalmazását - már 2000-ben, amikor a roziglitazon elöször forgalomba hozatali engedélyt kapott - másodvonalbeli terápiára szűkítették, és szívelégtelenségben, vagy az anamnézisben előforduló szívelégtelenség esetén ellenjavallttá tették.

Az SGLT2-gátlókkal végzett kardiovaszkuláris (CV) biztonságossági és hatékonysági vizsgálatok egyik konzekvens észlelése volt a szívelégtelenséghez köthető végpontok, elsősorban a szívelégtelenség miatti hospitalizáció markáns csökkenése, a vizsgálatok ezen fázisában értelemszerủen diabéteszben szenvedő betegekben. Utóbbit több SGLT2-gátlóval végzett CV kimeneti végpontú vizsgálat (5-8) és azok alcsoportelemzései (9-11), a CV-vizsgálatok metaanalízise (12), majd nagyszámú betegpopuláción észlelt „real-world” adatok is (13-16) egybehangzóan igazolták. Mindezek az adatok teremtették meg a tudományos alapot arra, hogy az eredetileg antidiabetikumként kifejlesztett SGLT2-gátlók hatásosságát HFrEF-ben szenvedő betegcsoportban vizsgálják, a diabétesz fennáltától függetlenül. Utóbbi vizsgálatok a klinikai vizsgálatok hierarchiájának csúcsán álló randomizált, kettős vak, placebokontrollált, multicentrikus vizsgálatokban, immár célzottan, nagyszámú HFrEF-betegpopulációban igazolták két SGLT2-gátló, a dapagliflozin és empagliflozin rizikócsökkentő hatását a CV-mortalitás és a szívelégtelenség miatti hospitalizáció vonatkozásában $(2,3)$. Jelen összefoglaló közlemény nem idörendi sorrendben, hanem az evidenciaszintek evolúciójának megfelelöen tekinti át az SGLT2-gátló kezelés bizonyítékait a szívelégtelenség, elsősorban a HFrEF terápiájának vonatkozásában. Az SGLT2-gátló szerek komplex hatásmechanizmusának tárgyalása nem képezi jelen közlemény tárgyát, erröl a témáról a Cardiologia Hungarica előző számában jelent meg egy részletes összefoglaló közlemény (17).

\section{Randomizált klinikai vizsgálatok: kardiovaszkuláris kimeneti végpontú vizsgálatok primer és szekunder prevenciós betegcsoportokban}

\section{Dapagliflozin: DECLARE}

A DECLARE (Dapagliflozin Effect on Cardiovascular Events) vizsgálat 2-es típusú diabéteszben szenvedő betegekben vizsgálta a dapagliflozin kardiovaszkuláris és renális események alakulására kifejtett hatását (18). A vizsgálatban 17160 beteg vett részt (dapagliflozin: $n=8574$; placebo: $n=8569$ ), a betegek $40,6 \%$-a szekunder prevenciós csoportba (ismert kardiovaszkuláris történés az anamnézisben), 59,4\%-uk primer prevenciós csoportba (kardiovaszkuláris kockázati tényezők az anamnézisben, úm. hipertónia, dyslipidaemia vagy dohányzás) tartozott. A vizsgálatba bevont betegek 10\%ában szerepelt szívelégtelenség a kórelőzményi adatok között. Az aktív ágon a betegek a megtartott korábbi antidiabetikus kezelés mellett napi $10 \mathrm{mg}$ dapagliflozint, a kontrollágon placebót kaptak. A követés tartama medián 4,2 év volt.

A dapagliflozin szignifikáns módon csökkentette a CV-halálozás vagy a szívelégtelenség miatti hospitalizáció összevont, társ-elsődleges (co-primary) végpontját (4,9\% vs. $5,8 \%$, HR: 0,$83 ; 95 \%$ Cl: $0,73-0,95)$. A változás hátterében döntően a szívelégtelenség miatti hospitalizáció csökkenése állt (HR: 0,$73 ; 95 \% \mathrm{Cl}$ : $0,61-0,88)$. A másik elsődleges végpont, a 3 pontos MACE (CV-halálozás, nem végzetes miokardiális infarktus és nem-végzetes stroke bekövetkezte) gyakorisága szignifikáns módon nem csökkent (HR: 0,93; $95 \% \mathrm{Cl}: 0,84-1,03)$. A renális események is szignifikánsan csökkentek, a mellékhatások között a dapagliflozinágon a ketoacidózis és a genitális mikotikus infekciók szignifikánsan gyakoribb előfordulását észlelték (7).

A DECLARE-vizsgálat szívelégtelen betegek alcsoportját elemző analízisében (10) a dapagliflozin hatásait a tanulmányba bevont HFrEF-es (EF $<45 \%, 671$ beteg, a teljes vizsgálati populáció $3,9 \%$-a) és nem HFrEF-es ( $E F>45 \%$, vagy nem szívelégtelenségben szenvedő) diabéteszes betegek között hasonlították össze. Az eredmények alapján a dapagliflozint szedő HFrEF-betegekben a CV-halálozás és a szívelégtelenség miatti hospitalizáció összetett végpontja $38 \%$-os csökkenést mutatott (HR: 0,62; $95 \% \mathrm{Cl}: 0,45-0,86)$ szemben a nem HFrEF-csoportban talált $12 \%$-os csökkenéssel (HR: 0,88; 95\% Cl: 0,66-1,17). A HFrEF-alcsoportban mind a CV-halálozás (HR: 0,55; 95\% Cl: 0,34-0,90), 
mind az összhalálozás (HR: 0,59; 95\% Cl: 0,40-0,88) szignifikánsan csökkent a dapagliflozint kapó csoportban (16).

\section{Empagliflozin: EMPA-REG OUTCOME}

AZ EMPA-REG OUTCOME-vizsgálat az empagliflozin kardiovaszkuláris eseményekre (CV-halálozás, nem-végzetes miokardiális infarktus és nem-végzetes stroke) gyakorolt hatását elemezte (19). A vizsgálatban 2-es típusú diabéteszben szenvedö, CV-kockázat szempontjából szekunder prevenciós csoportba tartozó, kórtörténetükben ismert kardiovaszkuláris eseménnyel/betegséggel (koszorúér-betegség, előzetes miokardiális infarktus, instabil angina, perifériás obliteratív érbetegség) rendelkező betegek vettek részt. Valamennyi beteg standard diabétesz terápiája mellé a betegek $10 \mathrm{mg}$ vagy $25 \mathrm{mg}$ empagliflozint vagy placebót kaptak (empagliflozin $10 \mathrm{mg}$ : $\mathrm{n}=2345$, empagliflozin 25 mg: $n=2342$, placebo: $n=2333$ ). A követés tartama medián 3,1 év volt.

Empagliflozin mellett szignifikánsan kevesebb CV-esemény következett be; az elsődleges végpontként meghatározott CV-halálozás, nem-végzetes miokardiális infarktus és nem végzetes stroke bekövetkeztét tekintve $14 \%$-os relatív kockázatcsökkenés mutatkozott az empagliflozin javára (HR: 0,86; 95\%-os Cl: 0,74-0,99). Utóbbit döntően a CV-halálozás csökkenése okozta, ebben a tekintetben a relatív kockázatcsökkenés 38\% volt (HR: 0,62; 95\%-os Cl: 0,49-0,77), hasonlóan elönyösen alakult az összhalálozás (HR: 0,68; $95 \% \mathrm{Cl}$ : $0,57-0,82$ ) és a szívelégtelenség miatti hospitalizáció (HR: 0,65; 95\% Cl: 0,50-0,85). A $10 \mathrm{mg}$ és $25 \mathrm{mg}$ empagliflozin kardiovaszkuláris eseményekre gyakorolt hatása lényegében azonos mértékủ volt. Az aktív ág számos renális kimeneteli végpontra (kialakuló vagy romló nephropathia, macroalbuminuriába történő progresszió, szérumkreatinin megkettőződése, vesepótló-kezelés megkezdése) is előnyösen hatott. A mellékhatások között az empagliflozin mellett nagyobb arányban jelentkező genitális infekció elöfordulása érdemel említést. A hypoglykaemia-események alakulása terén a vizsgálati csoportok között nem mutatkozott értékelhető különbség (8).

Az EMPA-REG OUTCOME szívelégtelen betegek alcsoportját elemző analízisében (9) annak a 706 betegnek (a teljes vizsgálati betegpopuláció 10,1\%-a) az adatait elemezték, akik a vizsgálói megítélés alapján szívelégtelenségben szenvedtek. A szívelégtelenség miatti hospitalizáció és CV-halálozás szignifikánsan alacsonyabb arányban fordult elő az empagliflozincsoportban (5,7\% vs. $8,5 \%$; HR: 0,$66 ; 95 \% \mathrm{Cl}$ : $0,55-0,79)$. Empagliflozin mellett a további SzE kimeneteli végpontok (SzE miatti hospitalizáció vagy halálozás: $2,8 \%$ vs. 4,5\%; HR: 0,61; 95\% Cl: 0,47-0,79), illetve a bármely ok miatti hospitalizáció (36,8\% vs. $39,6 \%$; HR: 0,89; $95 \%$ $\mathrm{Cl}: 0,82-0,96)$ is kedvezöbben alakultak. Az empagliflozinnak fenti hatása független volt a kovariánsoktól.

\section{Canagliflozin: CANVAS}

A canagliflozinnal folytatott CANVAS (Canagliflozin Cardiovascular Assessment Study) Program a canagliflozin kardiovaszkuláris biztonságosságát és renális hatásait megítélő vizsgálat volt (20). A vizsgálatban összesen 10142 felnőtt, 2-es típusú diabéteszben szenvedő beteg vett részt (betegek 65,6\%-ának kórelőzményében szerepelt ismert kardiovaszkuláris betegség). A standard antidiabetikus terápia mellett canagliflozint (napi $1 \times 100$ vagy $1 \times 300 \mathrm{mg}, \mathrm{n}=5795$ ), a kontrollágon $(n=4347)$ placebót kaptak. A követés mediántartama 3,6 év volt.

$\mathrm{Az}$ elsődleges összevont végpont (kardiovaszkuláris halál, nem végzetes miokardiális infarktus, nem végzetes stroke) kockázatának esélyhányadosa 0,86 (95\% $\mathrm{Cl}: 0,75-0,97)$ volt. Az első másodlagos végpontként meghatározott összmortalitást tekintve a két csoport között szignifikáns különbség nem volt, a hierarchikus tesztelésre való tekintettel a további analízisek tekintetében szignifikanciaszintet nem közöltek. A vizsgálatban az egyes renális végpontokban észlelt változás (szérumkreatinin kétszeres növekedése, végstádiumú veseelégtelenség, renális eredetủ halál, eGFR csökkenésének üteme, albuminuria kialakulása) a canagliflozin elönyére utalt. A mellékhatásokat illetően a canagliflozinágon az alsóvégtagi, döntően disztális amputációk gyakoribb voltát figyelték meg, a csonttörések kockázata is értékelhetően nagyobb volt (6).

Az CANVAS Program szívelégtelen betegek alcsoportját elemző analízisében (11) 1461 (a teljes vizsgálati betegpopuláció $14,4 \%$-a) szívelégtelen beteg (vizsgálói megítélés alapján) adatait elemezték. Összességében, a CV-halálozás és SzE miatti hospitalizáció szignifikánsan csökkent a canagliflozincsoportban (16,3 vs. 20,8/1000 betegév; HR: 0,78; 95\% Cl: 0.67-0,91), csakúgy, mint SzE miatti halálozás és hospitalizáció (HR: 0,70; 95\% Cl: 0,55-0,89) vagy a SzE miatti hospitalizáció önmagában (HR: 0,67; 95\% Cl: 0,52-0,87).

\section{Ertugliflozin: VERTIS-CV}

Az ertugliflozinnal kapcsolatban a VERTIS-CV (Evaluation of Ertugliflozin Efficacy and Safety Cardiovascular Outcomes Trial) vizsgálatban elemezték a készítmény kardiovaszkuláris biztonságosságát (21). A vizsgálatban 2-es típusú diabéteszben szenvedő, CV-kockázat szempontjából szekunder prevenciós csoportba tartozó, kórtörténetükben ismert kardiovaszkuláris eseménnyel/betegséggel (koszorúér-betegség, előzetes miokardiális infarktus, instabil angina, perifériás obliteratív érbetegség) rendelkező betegek vettek részt. A betegek standard diabéteszterápiája mellé a betegek $5 \mathrm{mg}$ vagy $15 \mathrm{mg}$ ertugliflozint vagy placebót kaptak. A vizsgálatba 8246 beteget randomizáltak, a követés tartama medián 3,5 év volt.

Az ertugliflozin- és placebocsoport között az elsődleges végpont tekintetében (3 pontos MACE: kardiovaszkuláris halál, nem végzetes miokardiális infarktus, nem 
végzetes stroke) statisztikailag szignifikáns non-inferioritás volt kimutatható $(11,9 \%$ vs. $11,9 \%$, HR: 0,97 ; 95,6\% Cl: 0,85-1,11). A CV-halálozás és SzE miatti hospitalizáció eseményrátája nem különbözött szignifikáns mértékben $(8,1 \%$ vs. $9,1 \%$, HR: 0,$88 ; 95,8 \% \mathrm{Cl}$ : 0,75-1,03). A hierarchikus tesztelés miatt statisztikailag nem elemzett, másodlagos végpontként meghatározott SzE miatti hospitalizáció jelentős csökkenés mutatott a kezelt csoportban (HR: 0,70, 95\% Cl: 0,54-0,90), míg az összhalálozás nem változott lényegesen (HR: 0,93; 95\% Cl: 0,80-1,08) (5).

\section{Kardiovaszkuláris kimeneti végpontú randomizált klinikai vizsgálatok metaanalízise primer és szekunder prevenciós betegcsoportokban}

A DECLARE eredményeinek publikálásával egy időben a Lancet-ben jelent meg az SGLT2-gátlókkal folytatott addigi nagy tanulmányok (EMPA-REG OUTCOME, CANVAS Program, DECLARE) metaanalízisének eredményei (12). A három vizsgálat összevonásával 34322 beteg adatait elemezték [szekunder prevenciós csoport, n=20 $650(60,2 \%)$, primer prevenciós csoport, $n=13672(39,8 \%)]$. Összességében véve SGLT2-gátlók mellett a MACE csökkenése $11 \%$ volt (HR: 0,89; 95\% Cl: 0,83-0,96). A csökkenés kizárólag a szekunder prevenciós csoportban mutatkozott (HR: 0,86; 95\% $\mathrm{Cl}$ : 0,80-0,93), a primer prevenciós csoportban érdemi csökkenés (HR: 1,00; 95\% Cl: 0,87-1,16) nem volt kimutatható.

Az SzE miatti hospitalizációt tekintve az SGLT2-gátlók szignifikánsan, 23\%-kal csökkentették a CV-halálozás vagy az SzE miatti hospitalizáció összevont végpontját (HR: 0,77; 95\% Cl: 0,71-0,84), és 31\%-kal az SzE miatti hospitalizáció egyedi végpontját (HR: 0,69; 95\% Cl: 0,61-0,79). A CV-halálozás vagy az SzE miatti hospitalizáció összevont végpontjának relatív kockázata a szekunder prevenciós csoportban 24\%-kal (HR: 0,76; 95\% Cl: 0,69-0,84), a primer prevenciós csoportban 16\%kal (HR: 0,84; 95\% Cl: 0,69-1,01) csökkent. A szívelégtelenség miatti hospitalizáció kockázata szempontjából a primer és a szekunder prevenciós csoportban egyformán hatásos volt az SGLT2-gátló kezelés. A metaanalízis adatai alapján a szívelégtelenség miatti hospitalizáció kockázatát az SGLT2-gátlók jobban csökkentették alacsonyabb eGFR esetén.

\section{„Real-world" adatok: primer és szekunder prevenciós betegcsoportok}

Dapagliflozin: CVD-REAL, CVD-REAL Nordic A nagy betegszámú, multicentrikus, retrospektív CVDREAL (Comparative Effectiveness of Cardiovascular Outcomes in New Users of SGLT-2 Inhibitors) „való világ" vizsgálatban az újonnan indított SGLT2-gátlók hatásosságát hasonlították össze más antidiabetikumokkal diabéteszes betegcsoportban (14). A vizsgálatban hat ország (Egyesült Államok, Egyesült Királyság, Svédország, Norvégia, Dánia, Németország) 309046 betegének adatait elemezték, a betegek 13\%-ának a kórtörténetében szerepelt igazolt CV-alapbetegség. Az SGLT2-ágon az addigi bázisterápia mellé újonnan indított SGLT2-gátló készítményt kaptak a betegek $(n=154528)$, míg a másik ágon $(n=154928)$ más, de szintén újonnan indított antidiabetikus kezelésben részesültek a betegek. A betegek 42\%-a dapagliflozin, $53 \%$-a canagliflozin és 5\%-a empagliflozinkezelésben részesült. A vizsgálatban az SzE miatti hospitalizáció rizikója 39\%-kal (HR: 0,6; 95\% Cl: 0,51-0,73), az összhalálozás kockázata 51\%-kal (HR: 0,49; 95\% Cl: 0,41-0,57), a szívelégtelenség miatti hospitalizáció és az összhalálozás összevont kockázata pedig 46\%-kal (HR: 0,54; 95\% Cl: 0,48-0,60) csökkent az SGLT2-gátlóval kezelt betegeknél (12).

A skandináv államok (Dánia, Norvégia, Svédország) adatai alapján végzett CVD-REAL Nordic tanulmányban (amelyben az SGLT2-ágon a betegek 94\%-a dapagliflozint kapott), a primer összetett végpontok tekintetében az eredmények hasonlóak voltak az eredeti tanulmányhoz $(13,16)$. A dapagliflozinágon átlagban 1 éves követés után a MACE 21\%-kal (HR: 0,79; 95\% Cl: 0,67-0,94), a szívelégtelenség miatti hospitalizáció 38\%-kal (HR: 0,62; 95\% Cl: 0,500,77), az összhalálozás pedig 41\%-kal (HR: 0,59; 95\% Cl: 0,49-0,72) csökkent a DPP4-gátlót szedő betegekhez képest.

A CVD-REAL 2-vizsgálat az első vizsgálattal azonos kivitelezésű vizsgálat volt, amelyet Japán, Dél-Korea, Szingapúr, Izrael, Ausztrália és Kanada adatbázisának felhasználásával végeztek. Az eredmények hasonlóak voltak a CVD-REAL eredményeihez (15).

\section{Empagliflozin: EMPRISE}

Az EMPRISE (EMPagliflozin compaRative effectiveness and SafEty) az empagliflozin hatékonyságának és biztonságosságának igazolására irányuló „real-world” vizsgálat volt, amelyet az Egyesült Államokban végeztek három adatbázisból azonosított, „propensity-score matching” alapján homogenizált, 2-es típusú diabéteszben szenvedő 16443 beteg 2014-2016 közötti adatainak elemzésével (22). A vizsgált betegek kb. 25\%-ának volt megelőzően CV-betegség az anamnézisében.

Sitagliptinnel összehasonlítva, az empagliflozincsoportban az elsődleges kiíró diagnózisként meghatározott SzE miatti hospitalizáció rizikója 50\%-kal (HR: 0,50; 95\% Cl: 0,28-0,91), a bármely kiíró diagnózisként meghatározott SzE miatti hospitalizáció rizikója pedig 49\%-kal (HR: 0,51; 95\% Cl: 0,39-0,68) csökkent, a medián 5,3 hónapos utánkövetés alatt. Az anamnézisükben SzE diagnózisával rendelkező betegekben a relatív rizikó 46-39\%-kal csökkent (23). 
Randomizált klinikai vizsgálatok: csökkent ejekciós frakcióval járó (HFrEF)

\section{betegcsoportban}

\section{Dapagliplozin: DAPA-HF}

A DAPA-HF-vizsgálat (Dapagliflozin and Prevention of Adverse-outcomes in Heart Failure) egy randomizált, kettős vak, multicentrikus, placebokontrollos vizsgálat volt, amelyben a dapagliflozin hatásosságát és biztonságosságát vizsgálták HFrEF-ben szenvedő, optimalizált terápia alatt álló betegekben (2). A betegek az aktív ágon $(n=2373)$ napi $10 \mathrm{mg}$ dapagliflozint, a kontrollágon ( $\mathrm{n}=2371)$ placebót kaptak, a vizsgálatba bevont betegek mindössze $45 \%$-a volt diabéteszes.

Az átlagosan 18 hónapos követési időt követően a dapagliflozinágon az elsődleges végpontként meghatározott CV-halálozás vagy az SzE súlyosbodása (SzE miatti hospitalizáció vagy SzE miatti sürgős orvosi ellátás) szignifikáns, $26 \%$-os relatív kockázatcsökkenést mutatott (HR: 0,74; 95\% Cl: 0,65-0,85). A végpontkompozitok közül a CV-halálozás relatív kockázatcsökkenése 18\% (HR: 0,82; 95\% Cl: 0,69-0,98), az SzE súlyosbodásának relatív kockázatcsökkenése $30 \%$ (HR: 0,70; $95 \% \mathrm{Cl}: 0,59-0,83)$ volt. A primer végpont rizikójának csökkenése közel azonos volt a diabéteszben szenvedők (HR: 0,75; 95\% Cl: 0,63-0,90) és a nem diabéteszesek (HR: 0,73; 95\% Cl: 0,60-0,88) csoportjában. A másodlagos végpontként meghatározott összmortalitás a dapagliflozinágon szintén szignifikánsan, 17\%-kal csökkent (HR: 0,83; 95\% Cl: 0,71-0,97) (2).

Az adverz események (exsiccosis, hypoglykaemia, veseelégtelenség) gyakorisága nőtt az életkorral, azonban egyik sem volt szignifikánsan gyakoribb az aktív ágon. Ugyancsak nem volt különbség a két ág között a tolerabilitás és a biztonságosság tekintetében.

\section{Empagliflozin: EMPEROR-Reduced}

Az EMPEROR-Reduced- (Empagliflozin Outcome Trial in Patients with Chronic Heart Failure and Reduced Ejection Fraction) vizsgálatban az empagliflozin hatásosságát vizsgálták HFrEF-ben szenvedő szívelégtelen betegekben (3). A kettős vak, randomizált, multicentrikus vizsgálatba NYHA II-IV. stádiumú, 40\% alatti ejekciós frakciójú HFrEF-betegeket randomizáltak $(n=3730)$. A szívelégtelenség optimalizált terápiája mellett az aktív ágon $(n=1863)$ a betegek $10 \mathrm{mg} \mathrm{em}$ pagliflozint kaptak. Az utánkövetés medián időtartama 16 hónap volt.

$\mathrm{Az}$ elsődleges kompozit végpont (CV-halálozás vagy SzE miatti hospitalizáció) előfordulási gyakorisága szignifikánsan csökkent az empagliflozinágon (19,4\% vs. 24,7\%; HR: 0,75; 95\% Cl: 0,65-0,86). Az empagliflozin hatékonysága azonos volt a diabéteszes és a nem-diabéteszes csoportban. Az SzE miatti összes hospitalizáció végpontjában az empagliflozinágon $30 \%$-os relatív kockázatcsökkenést lehetett észlelni (HR 0,70; 95\% $\mathrm{Cl}$ : 0,58-0,85). A vizsgálat vesevégpontjai (az átlagos
eGFR éves csökkenése, súlyos renális kimenetel) is kedvezőbbek voltak az empagliflozinágon. Az összhalálozás szignifikánsan nem különbözött a két csoportban (HR: 0,92; 95\% Cl: 0,77-1,10). Genitális infekció gyakrabban fordult elő az empagliflozinágon (3).

\section{SGLT2-gátló kezelés a klinikai ajánlásokban}

Az Európai Kardiológus Társaság (ESC) és az Európai Diabetes Társaság (European Association for the Study of Diabetes, EASD) közös irányelve a diabétesz és a kardiovaszkuláris betegségek ellátásáról 2019ben jelent meg (24). Az irányelv már külön fejezetben tárgyalja a szívelégtelenség kezelésével kapcsolatos ajánlásokat diabéteszes betegekben és IA indikációval javasolja az SGLT2-gátlókat (empagliflozin, canagliflozin, dapagliflozin) diabéteszben szenvedő betegeknél a szívelégtelenség miatti hospitalizáció kockázatának csökkentése céljából.

Az ESC Szívelégtelenség Társasága (Heart Failure Association, HFA) 2018-ban publikált (25), a diabétesz és a szívelégtelenség együttes kezeléséröl szóló „ESC HFA position statement"-je rövid időn belül két frissítésen is átesett, elöször 2020 februárjában (26), majd 2020 októberében (27). A HFA a 2020 októberében kiadott állásfoglalásában a következő ajánlást adja:

- A canagliflozin, dapagliflozin, empagliflozin, vagy ertugliflozin konzisztens módon igazolta, hogy hatásosak az SzE hospitalizációjának megelőzése céljából 2-es típusú diabéteszben szenvedő betegekben, igazolt CV-betegség vagy magas $\mathrm{CV}$-rizikó esetén. Fenti célra a felsorolt szerek a javasoltak.

- Dapagliflozin vagy empagliflozin javasolt az SzE miatti hospitalizáció és CV-halálozás kombinált rizikójának csökkentésére tünetekkel rendelkező, az ajánlásokban javasolt gyógyszeres terápia alatt álló HFrEF-betegekben, a 2-es típusú diabétesz fennálltától függetlenül.

Az ESC új szívelégtelenséggel kapcsolatos irányelve 2021-ben várható, amely feltehetően a bővülő eredmények tükrében fentiekhez hasonló módon már be fogja építeni az SGLT2-gátló terápiát a HFrEF gyógyszeres kezelésének algoritmusába diabétesz fennálltától függetlenül. A nemzetközi szakmai ajánlásokban megfogalmazott terápiás algoritmus változását pedig remélhetőleg Magyarországon is követi majd az új indikáció befogadása és a szerek támogathatóságának megváltozása.

\section{Összefoglalás}

Az SGLT2-gátlók hatásosságát HFrEF-ben a klinikai vizsgálatok teljes spektruma igazolja, a CV kimeneti végpontú vizsgálatok és azok alcsoportelemzéseitől kezdve, a CV-vizsgálatok metaanalízisein, „real-world” adatokon át egészen a célzott HFrEF-betegpopulációkat vizsgáló randomizált, placebokontrollált, multicentrikus 
vizsgálatokkal bezárólag. Fenti vizsgálatok konzisztens módon igazolják az SGLT2-gátló szerek morbiditás- és mortalitáscsökkentő hatását HFrEF-betegekben, fennálló diabétesztől függetlenül. Ezen adatokon alapulva vezető szakmai szervezetek már jelenleg is ajánlásként fogalmazzák meg az SGLT2-gátlók használatát az SzE hospitalizációjának megelőzése céljából 2-es típusú diabéteszben szenvedő betegekben, illetve specifikusan a dapagliflozin vagy empagliflozin alkalmazását az SzE miatti hospitalizáció és CV-halálozás kombinált rizikójának csökkentésére tünetes HFrEF-betegekben, diabétesz fennálltától függetlenül. Az ESC új szívelégtelenséggel kapcsolatos irányelve várhatóan szintén be fogja építeni az SGLT2-gátló terápiát a HFrEF gyógyszeres kezelésének algoritmusába.

\section{Nyilatkozat \\ A közlemény megjelenését az AstraZeneca Kft. támo- gatta. A cikkben megfogalmazottak a szerző saját vé- leményét tükrözik. Az AstraZeneca Kft. az általa forgal- mazott készítmények alkalmazását csak az érvényes hazai alkalmazási elöirásoknak megfelelően javasolja.}

\section{Irodalom}

1. Verma S, McMurray JJV. SGLT2 inhibitors and mechanisms of cardiovascular benefit: a state-of-the-art review. Diabetologia 2018; 61(10): 2108-17. https://doi.org/10.1007/s00125-018-4670-7

2. McMurray JJV, Solomon SD, Inzucchi SE, et al. Dapagliflozin in Patients with Heart Failure and Reduced Ejection Fraction. N Engl J Med 2019; 381(21): 1995-2008.

https://doi.org/10.1056/NEJMoa1911303

3. Packer M, Anker SD, Butler J et al. Cardiovascular and Renal Outcomes with Empagliflozin in Heart Failure. N Engl J Med 2020; 383(15): 1413-24. https://doi.org/10.1056/NEJMoa2022190

4. Lago RM, Singh PP, Nesto RW. Congestive heart failure and cardiovascular death in patients with prediabetes and type 2 diabetes given thiazolidinediones: a meta-analysis of randomised clinical trials. Lancet 2007; 370(9593): 1129-36.

https://doi.org/10.1016/S0140-6736(07)61514-1

5. Cannon CP, Pratley R, Dagogo-Jack S, et al. Cardiovascular Outcomes with Ertugliflozin in Type 2 Diabetes. N Engl J Med 2020; 383(15): 1425-35. https://doi.org/10.1056/NEJMoa2004967

6. Neal B, Perkovic V, Mahaffey KW, et al. Canagliflozin and Cardiovascular and Renal Events in Type 2 Diabetes. N Engl J Med 2017; 377(7): 644-57. https://doi.org/10.1056/NEJMoa1611925

7. Wiviott SD, Raz I, Bonaca MP, et al. Dapagliflozin and Cardiovascular Outcomes in Type 2 Diabetes. N Engl J Med 2019; 380(4): 347-57. https://doi.org/10.1056/NEJMoa1812389

8. Zinman B, Wanner C, Lachin JM, et al. Empagliflozin, Cardiovascular Outcomes, and Mortality in Type 2 Diabetes. N Engl J Med 2015; 373(22): 2117-28. https://doi.org/10.1056/NEJMoa1504720

9. Fitchett $D$, Zinman B, Wanner $C$, et al. Heart failure outcomes with empagliflozin in patients with type 2 diabetes at high cardiovascular risk: results of the EMPA-REG OUTCOME(R) trial. Eur Heart J 2016; 37(19): 1526-34. https://doi.org/10.1093/eurheartj/ehv728

10. Kato ET, Silverman MG, Mosenzon O, et al. Effect of Dapagliflozin on Heart Failure and Mortality in Type 2 Diabetes Mellitus. Circulation 2019; 139(22): 2528-36.

https://doi.org/10.1161/CIRCULATIONAHA.119.040130

11. Radholm K, Figtree G, Perkovic V, et al. Canagliflozin and Heart Failure in Type 2 Diabetes Mellitus: Results From the CANVAS Program. Circulation 2018; 138(5): 458-68. https://doi.org/10.1161/CIRCULATIONAHA.118.034222

12. Zelniker TA, Wiviott SD, Raz I, et al. SGLT2 inhibitors for primary and secondary prevention of cardiovascular and renal outcomes in type 2 diabetes: a systematic review and meta-analysis of cardio- vascular outcome trials. Lancet 2019; 393(10166): 31-9.

https://doi.org/10.1016/S0140-6736(18)32590-X 1

13. Birkeland $\mathrm{KI}$, Jorgensen ME, Carstensen B, et al. Cardiovascular mortality and morbidity in patients with type 2 diabetes following initiation of sodium-glucose co-transporter-2 inhibitors versus other glucose-lowering drugs (CVD-REAL Nordic): a multinational observational analysis. Lancet Diabetes Endocrinol 2017; 5(9): 709-17. https://doi.org/10.1016/S2213-8587(17)30258-9

14. Kosiborod M, Cavender MA, Fu AZ, et al. Lower Risk of Heart Failure and Death in Patients Initiated on Sodium-Glucose Cotransporter-2 Inhibitors Versus Other Glucose-Lowering Drugs: The CVD-REAL Study (Comparative Effectiveness of Cardiovascular Outcomes in New Users of Sodium-Glucose Cotransporter-2 Inhibitors). Circulation 2017; 136(3): 249-59.

https://doi.org/10.1161/CIRCULATIONAHA.117.029190

15. Kosiborod M, Lam CSP, Kohsaka S, et al. Cardiovascular Events Associated With SGLT-2 Inhibitors Versus Other Glucose-Lowering Drugs: The CVD-REAL 2 Study. J Am Coll Cardiol 2018; 71(23): 2628-39. https://doi.org/10.1016/j.jacc.2018.03.009

16. Persson F, Nystrom T, Jorgensen ME, et al. Dapagliflozin is associated with lower risk of cardiovascular events and all-cause mortality in people with type 2 diabetes (CVD-REAL Nordic) when compared with dipeptidyl peptidase-4 inhibitor therapy: A multinational observational study. Diabetes Obes Metab 2018; 20(2): 344-51. https://doi.org/10.1111/dom.13077

17. Szekeres ZsJ, Stolz T, Szabados E. A nátrium-glükóz-kotranszporter-2-gátlók a diabetes mellitus kezelésén túl. Cardiologia Hungarica 2020; 50: 372-7. DOI: 10.26430/CHUNGARICA.2020.50.5.372 18. Wiviott SD, Raz I, Bonaca MP, et al. The design and rationale for the Dapagliflozin Effect on Cardiovascular Events (DECLARE)-TIMI 58 Trial. Am Heart J 2018; 200: 83-9.

https: //doi.org/10.1016/j.ahj.2018.01.012

19. Zinman B, Inzucchi SE, Lachin JM, et al. Rationale, design, and baseline characteristics of a randomized, placebo-controlled cardiovascular outcome trial of empagliflozin (EMPA-REG OUTCOME). Cardiovasc Diabetol 2014; 13: 102

https://doi.org/10.1186/1475-2840-13-102

20. Neal B, Perkovic V, Matthews DR, et al. Rationale, design and baseline characteristics of the CANagliflozin cardioVascular Assessment Study-Renal (CANVAS-R): A randomized, placebo-controlled trial. Diabetes Obes Metab 2017; 19(3): 387-93.

https://doi.org/10.1111/dom.12829

21. Cannon CP, McGuire DK, Pratley R, et al. Design and baseline characteristics of the eValuation of ERTugliflozin efflcacy and Safety CardioVascular outcomes trial (VERTIS-CV). Am Heart J 2018; 206: 11-23. https://doi.org/10.1016/j.ahj.2018.08.016

22. Patorno E, Najafzadeh M, Pawar A, et al. The EMPagliflozin compaRative effectlveness and SafEty (EMPRISE) study programme: Design and exposure accrual for an evaluation of empagliflozin in routine clinical care. Endocrinol Diabetes Metab 2020; 3(1): e00103. https://doi.org/10.1002/edm2.103

23. Patorno E, Pawar A, Franklin JM, et al. Empagliflozin and the Risk of Heart Failure Hospitalization in Routine Clinical Care. Circulation 2019; 139(25): 2822-30.

https://doi.org/10.1161/CIRCULATIONAHA.118.039177

24. Cosentino F, Grant PJ, Aboyans V, et al. 2019 ESC Guidelines on diabetes, pre-diabetes, and cardiovascular diseases developed in collaboration with the EASD. Eur Heart J 2020; 41(2): 255-323. https://doi.org/10.1093/eurheartj/ehz486

25. Seferovic PM, Petrie MC, Filippatos GS, et al. Type 2 diabetes mellitus and heart failure: a position statement from the Heart Failure Association of the European Society of Cardiology. Eur J Heart Fail 2018; 20(5): 853-72. https://doi.org/10.1002/ejhf.1170

26. Seferovic PM, Coats AJS, Ponikowski P, et al. European Society of Cardiology/Heart Failure Association position paper on the role and safety of new glucose-lowering drugs in patients with heart failure. Eur J Heart Fail 2020; 22(2): 196-213. https://doi.org/10.1002/ejhf.1673

27. Seferovic PM, Fragasso G, Petrie M, Mullens W, Ferrari R, Thum $\mathrm{T}$, et al. Heart Failure Association of the European Society of Cardiology update on sodium-glucose co-transporter 2 inhibitors in heart failure (an update on the sodium-glucose co-transporter 2 inhibitors in heart failure: beyond glycaemic control. A position paper of the Heart Failure Association of the European Society of Cardiology). Eur J Heart Fail 2020. https://doi.org/10.1002/ejhf.2026 